\title{
ELEMENTY TEOLOGII MISTYCZNEJ ŚW. BONAWENTURY Z BAGNOREGIO
}

\section{Wstęp}

We wstępie do publikacji czterech najważniejszych pism ascetyczno-mistycznych św. Bonawentury (1217-1274) pod ogólnym tytułem Droga duszy do Boga ${ }^{1}$ można przeczytać, że Doktor Seraficki jest postacią historyczną, której twórczości nie sposób zamknąć w jakimś upraszczającym schemacie. Nie da się go łatwo zaszeregować do danego nurtu myślowego ani też wcisnąć sztandarowo w ramy epoki bez obawy pomniejszenia jego indywidualności. Jedni określają Bonawenturę jako eklektyka wybujałego w swojej erudycji i zamiłowaniu do symboli, inni natomiast podkreślają jego zdolność komponowania wielkich konstrukcji analitycznych.

Autor wstępu opisuje go następująco: „Św. Bonawentura - wśród dysputujących szkolarzy [...] zbyt żarliwie pobożny, wśród roznamiętnionych pietystów [...] zbyt uczony, wśród odkrywców pogańskiej mądrości [...] zbyt zazdrosny miłośnik Chrystusowej ortodoksji, wśród mocarnych ascetów [...] zbyt kruchego zdrowia, wśród idealistów Franciszkowego ducha [...] zbyt roztropny obrońca franciszkańskiej instytucji zakonnej"”.

Kanonizowany w 1482, ogłoszony doktorem Kościoła w 1588 r. jako Doktor Seraficki z racji częstego odwoływania się do hierarchii anielskich będących wzorem dla Kościoła walczącego ${ }^{3}$ - pod koniec XIX w. został nazwany przez Leona XIII „księciem teologii mistycznej”4. W liście do generała Zakonu Braci Mniejszych papież ten tak wyraził się o św. Bonawenturze: „Ponieważ w najwyższym stopniu wszedł na trudne szczyty spekulacji i tak doskonale rozwijał teologię mistyczną, dlatego według zgodnej opinii znawców uważać go trzeba za księcia wśród mistyków”. Co więcej, w tym samym liście Leon XIII zamieścił też osobiste wyznanie: „Często

1 Św. Bonawentura, Droga duszy do Boga, w: Św. Bonawentura, Droga duszy do Boga $i$ inne traktaty, tłum. C. Napiórkowski, C. Niezgoda, S. Kafel, wstęp Paweł Milcarek, Biblioteka Christianitas 7, Poznań 2001.

2 P. Milcarek, Wstęp, w: Św. Bonawentura, Droga duszy do Boga ..., dz. cyt., s. 6.

3 Św. Bonawentura na najwyższym anielskim szczeblu serafinów symbolizujących najżarliwszą miłość i ekstazę ducha umieścił samego św. Franciszka, którego uznawał za Świętego Serafickiego. W przyszłości Kościół jemu nada tytuł Doktora Serafickiego.

4 Leon XIII, Alokacja do wykładowców Kolegium św. Antoniego, 11 XI 1890 r. Powtórzył to określenie papież Paweł VI w Liście z okazji siedemsetlecia śmierci św. Bonawentury, 15 VII 1974 r. „L’Osservatore Romano” 114 (1974), nr 176, s. 1n. 
i chętnie czytamy tego Doktora. $Z$ tej lektury odnosimy niewiarygodną wręcz rozkosz ducha i prawie że unosimy się ku niebu; on bowiem prowadzi do Boga"s.

Wielcy znawcy kultury i myśli średniowiecza nie szczędzą pochwał Doktorowi Serafickiemu jako mistykowi. Étienne Gilson stwierdza np., że nauka Bonawentury oznacza punkt szczytowy mistyki chrześcijańskiej i stanowi syntezę najbardziej kompletną, jakiej nigdy przedtem nie dokonano. Podkreślając doktrynalny charakter myśli duchowej Bonawentury, Gilson z upodobaniem nazywa ją „metafizyką mistyki chrześcijańskiej”。.

W niniejszym studium przedstawia się podstawowe elementy mistyki św. Bonawentury na podstawie tekstów zajmujących znaczące miejsce w kanonie mistyki franciszkańskiej. Piśmiennictwo Bonawentury koncentruje się zasadniczo wokół drogi (itinerarium), jaką ludzka dusza ma do pokonania, by osiągnąć Boga - ostateczny i w pełni uszczęśliwiający cel życia. Przedmiotem jego dociekań jest więc cała dynamika duchowego wysiłku człowieka zmierzającego do zjednoczenia z Bogiem w osobie Jezusa Chrystusa. Próby opisu tej dynamiki wraz z bogatą gamą terminologii, która ją specyfikuje i wyraża, znajdują się w licznych pismach traktujących o rozwoju życia duchowego na wszystkich jego etapach.

Trzeba w tym miejscu jeszcze zaznaczyć, że w ujęciu Bonawentury „mistyka nie ogranicza się do jakichś stanów nadzwyczajnych, lecz rozciąga się na całe życie chrześcijańskie. Jest realnym, choć ukrytym działaniem Boga w duszy, dzięki któremu ta ostatnia podąża ku najściślejszemu zjednoczeniu ze swym Stwórcą. $\mathrm{W}$ takim rozumieniu mistyka jest zharmonizowana - a nie przeciwstawiona $\mathrm{z}$ ascezą jako zespołem praktyk pobożnych, $\mathrm{z}$ ich skutkami w warstwie poznania, woli i zmysłów" . Jak słusznie zauważył kiedyś Apoloniusz Żynel, to Bonawenturze chrześcijaństwo zawdzięcza organiczne i funkcjonalne wszczepienie ascezy w nurt życia mistycznego ${ }^{8}$. Tym sposobem asceza przestaje być dobrowolnym dodatkiem do życia religijnego, a staje się jednym z żywotnych jego elementów.

5 Leon XII, Epistola summi pontifecis ad japoniae imperatorem (I),Acta Ordinis Fratrum Minorum" 9 (1890), s. 177-178.

6 Zob. É. Gilson, La philosophie de saint Bonaventure, Paris 1943, s. 396. Podobne opinie można znaleźć w następujących opracowaniach: V. Rolandetti, Esperienza metafisica ed esperienza mistica in s. Bonaventura: un sapere che ama e un amore che sa, w: San Bonaventura maestro di vita francescana e di sapienza cristiana: Atti del Congresso internazionale per il 7 centenario di San Bonaventura da Bagnoregio, Roma 19-26 settembre 1974, a cura di A. Pompei, vol. 3, Roma 1976, s. 387-394; I. Höllhuber, S. Bonaventura maestro della vera mistica malintesa dal misticismo moderno, w: San Bonaventura maestro di vita francescana ..., vol. 3, dz. cyt., s. 419-425; F. La Scala, Il rapporto tra scienza e verità nel misticismo di s. Bonaventura, w: San Bonaventura maestro di vita francescana..., vol. 3, dz. cyt., s. 503-506.

7 Św. Bonawentura, Droga duszy do Boga..., dz. cyt., s. 10.

8 Zob. A. Żynel, Droga ku Bogu poprzez ascezę wedlug św. Bonawentury, w: Św. Bonawentura. Życie i myśl, red. S.C. Napiórkowski, E.I. Zieliński, Niepokalanów-Warszawa 1976, S. 362 . 
A zatem dla Doktora Serafickiego asceza i mistyka stanowią dwie nierozerwalne strony tej samej rzeczywistości duchowej. Wydaje się, że z tego właśnie względu pierwsze obszerniejsze tłumaczenie na język polski pism poruszających tematykę duchowego itinerarium wydawca opatrzył podwójnym przymiotnikiem: ascetyczno-mistyczne .

\section{Drogi mistycznego poznania a cognitio experimentalis}

Przed odniesieniem się do kwestii mistycznego poznania Boga u Bonawentury, złożonego w swojej strukturze i wyrażonego szeroką paletą pojęć, trzeba przywołać fundamentalne założenie Pseudo-Dionizego Areopagity w badanej kwestii, ponieważ jego dorobek stanowił dla Doktora z Bagnoregio ważny punkt odniesienia przy formułowaniu własnych rozwiązań na ten temat ${ }^{10}$.

Otóż Pseudo-Dionizy zakładał, że Bóg jest „,nadniepoznawalny” (hyperagnostos) i że w takim razie można Go poznać jedynie ,ponad rozumem”, czyli przez doświadczenie mistyczne. Na tej płaszczyźnie, doskonalszej od katafatycznego i apofatycznego procesu poznawczego, człowiek przechodzi od myślenia ukierunkowanego na to, co jest, do wewnętrznego doświadczenia, czyli ekstazy ${ }^{11}$.

Odnosząc do Boga imiona wzięte z Pisma Świętego, Pseudo-Dionizy wychwycił ich ograniczoność i niewystarczalność, a to z tego względu, że są one tworami ludzkimi. Każdy zgadza się ze stwierdzeniem, że Bóg jest dobry, ale nie w takim znaczeniu jak dobrzy są ludzie. On jest więcej niż dobry, On jest najlepszy. Pseudo-Dionizy naucza zatem, że każde dobro odnosi się do czegoś najlepszego, podobnie jak skończone odnosi się do nieskończonego. Tym samym negacja treści jakiegoś terminu określana jako metoda apofatyczna doprowadziła go do odniesienia wszystkiego do Absolutu, który jest ponad tym wszystkim ${ }^{12}$. Apofatyczność pozyskiwania pojęć jest niejako obrazem apofatycznie skonstruowanej rzeczywistości. A to oznacza, że każda rzecz określa jej odniesienie do Absolutu. Jak zaznaczył Mieczysław Gogacz, w neoplatonizmie klasycznym jest to relacja

9 Św. Bonawentura, Pisma ascetyczno-mistyczne, Warszawa 1984.

10 Spośród autorów, do których Bonawentura odwoływał się najczęściej, na uprzywilejowanym miejscu znajduje się Pseudo-Dionizy Areopagita. Już w drugiej księdze Sentencji poruszającej zagadnienia angelologii opowiada się on za dionizyjską klasyfikację chórów anielskich, a nie za klasyfikacją Grzegorza Wielkiego.

11 Zob. R. Heinzmann, Filozofia średniowiecza, tłum. P. Domański, Kęty 1999, s. 109-110.

12 Pseudo-Dionizy Areopagita, Imiona boskie, w: Pseudo-Dionizy Areopagita, Pisma teologiczne. Imiona boskie. Teologia mistyczna. Listy, thum. M. Dzielska, Kraków 1997, s. 111. „Boskie imię dobra, które objawia wszelkie następstwa udzielania się przyczyny wszystkiego, rozciąga się na wszystkie byty i niebyty i jest ponad wszystkimi bytami i niebytami. Imię bytu obejmuje więc wszystko, co jest, a jednak jest ponad wszystkim, co jest. Imię życia rozciąga się na wszystko, co żyje, a jednak jest ponad wszystkim, co żyje. Mądrość natomiast jest mianem wszystkiego, co rozumne, co obdarzone intelektem i zmysłami, niemniej jednak jest ponad tym wszystkim". 
odległości, natomiast w neoplatonizmie średniowiecznym, którego reprezentantem był Bonawentura, jest to relacja podobieństwa ${ }^{13}$.

\section{Pytanie o cel teologicznego poznania w ogóle}

Św. Bonawentura uporządkował myśl Dionizego. Wyodrębnił w niej przejście od teologii spekulatywnej do teologii mistycznej, dając do zrozumienia, że teologia jako taka jest wiedzą nie tyle spekulatywną, ile bardziej afektywną, która winna prowadzić do miłości ${ }^{14}$.

O tym afektywnym charakterze teologii u Bonawentury pisał Joseph Ratzinger w jednym ze swoich opracowań. W kontekście pytania stawianego często nie tylko w okresie scholastycznym, czy i dlaczego należy próbować zastosowania metod myślenia filozoficznego do zrozumienia biblijnego orędzia, papież Benedykt zauważył dwie odpowiedzi obecne w systemie bonawenturiańskim. Pierwsza z nich przywołuje słowa z Pierwszego Listu św. Piotra, które dla doktorów średniowiecza stanowiły dostateczną rację uzasadniającą refleksję teologiczną: „Bądźcie zawsze gotowi do obrony wobec każdego, kto domaga się od was uzasadnienia tej nadziei, która w was jest” (1 P 3,15). Odpowiedź ta zatem dotyczy podłoża apologetycznego w teologii: trzeba uzasadnić, dlaczego się wierzy, trzeba wiarę wyjaśnić drugiemu. Oznacza to najwyraźniej, że wiara nie jest czysto osobową, czyli stricte indywidualną decyzją, nie dotyczącą innych. Co więcej, chce i może być zrozumiała także dla kogoś innego ${ }^{15}$.

${ }_{13}$ M. Gogacz, Apofatyka jako sposób opisu doświadczenia mistycznego w tekstach św. Bonawentury, w: Św. Bonawentura. Życie i myśl, dz. cyt., s. 388.

14 Tak pisał o apofatyce jako drodze wznoszenia się do Boga, podkreślając pierwszorzędne znaczenie uczucia wewnętrznego: „Ale istnieje inne, bardziej znamienite wznoszenie się do Boga, mianowicie po drodze negacji, ponieważ jak mówi Dionizy, «twierdzenia nie są ścisłe, przeczenia są prawdziwe», bo chociaż zdają się mniej mówić, mówią więcej. Ten sposób wznoszenia się do Boga dokonuje się przez zaprzeczenie wszystkiego, tak żeby w tych zaprzeczeniach był porządek, rozpoczynając od najniższych, a kończąc na najwyższych, a także aby zawierało się w nich najznamienitsze twierdzenie, na przykład mówiąc: Bóg nie jest czymś zmysłowym, rozumiemy, że jest ponadzmysłowy, a mówiąc, że nie jest ani wyobrażalny, ani pojęty, ani bytujący, rozumiemy, że jest kimś ponad to wszystko. Wtedy widok prawdy wchodzi do ciemności umysłu i wznosi się wyżej i wkracza głębiej, dlatego że przechodzi samego siebie i wszystko, co stworzone. To jest najdoskonalszy sposób podnoszenia umysłu do Boga, wszakże do swojej doskonałości wymaga tamtego drugiego, podobnie jak doskonałość wymaga oświecenia i jak przeczenie wymaga twierdzenia. Ten sposób wstępowania do Boga jest silniejszy, im siła wstępująca jest bardziej wewnętrzna, jest tym owocniejszy, im bliżej towarzyszy mu uczucie. Dlatego praktykowanie go jest bardzo pożyteczne". Św. Bonawentura, Trzy drogi albo inaczej ogień miłości, tłum. C. Niezgoda, III, 13, w: Św. Bonawentura, Pisma ascetyczno-mistyczne, dz. cyt., s. 30.

15 J. Ratzinger, Prawda w teologii, tłum. M. Mijalska, Kraków 2005, s. 27-28. 
O ile pierwsza odpowiedź uwzględniająca uzasadnienie wiary jest wspólna autorom scholastycznym, o tyle druga stanowi poniekąd znak firmowy Bonawentury. Racja zaś w niej ukryta zdaniem J. Ratzingera ma - ujmując rzecz współcześnie charakter misyjny. Otóż zdając sobie sprawę, że połączenie filozofii z teologią może przysparzać problemów, Bonawentura dostrzega potrzebę rozszerzenia poznania teologicznego o jeszcze jedną rację. Może być bowiem tak, że wiara chce zrozumieć z miłości do tego, którego obdarzyła swoją akceptacją ${ }^{16}$. Oznacza to, że w tym przypadku miłość szuka zrozumienia (amor quaerens intellectum). Chce coraz lepiej rozumieć tego, kogo kocha. Kochać, mówiąc najprościej, znaczy chcieć poznać. W ten sposób szukanie zrozumienia może być właśnie wewnętrznym nakazem miłości. Dla Bonawentury ważne jest więc to, aby dowartościować związek między miłością a prawdą, istotny zarówno dla teologii, jak i dla filozofii. Wiara chrześcijańska będzie mogła wówczas powiedzieć, że znalazła miłość. Trzeba jednak zaznaczyć, że miłość do Boga i do bliźniego ze względu na Boga może być trwała tylko wówczas, gdy jest miłością do prawdy ${ }^{17}$.

Tok myślenia jest prosty: poznanie prawdy rodzi się z miłości do niej i pogłębia miłowanie. Zgodnie z intuicją Doktora Serafickiego teologiczne poznanie Boga nie dąży do rozumowego przyjęcia tego, co On chce człowiekowi dać poznać, ale do udziału, czyli zjednoczenia, które możliwe jest tylko przez miłość. Końcem poznania teologicznego jest więc mistyczna jedność, czyli świętość. Ta zaś jest miłosnym oddaniem się Temu, który pragnie doprowadzić człowieka do pełnego zjednoczenia na drodze, na której mu się powierza.

Ważne miejsce odgrywa tu kategoria określana mianem docta ignorantia, która dotyczy właśnie zjednoczenia duszy z Bogiem. W takim stanie dusza jest w kontakcie z Prawdą absolutną, której nie jest w stanie wyrazić, i z Miłością równie absolutną, której słodyczą się nasyca. Tak więc sfera intelektualna spoczywa, gdyż jest bezradna wobec boskiej „,ciemności”, podczas gdy afektywna czuwa ${ }^{18}$. Ukazuje się tu osobliwa droga jednostki wynoszonej w mocy łaski ku mistycznym doświadczeniom. Człowiek

16 Św. Bonawentura, Liber Sententiarum, Prooemium, qu. 2, ad 6: „Sed quando fides non assentit propter rationem, sed propter amorem eius cui assentit, desiderat habere rationes". Doctoris seraphici S. Bonaventurae, Commentaria in quatuor libros Sententiarum Magistri Petri Lombardi, t. 1, Ad claras Aquas (Quaracchi) prope Florentiam: Ex typographia Colegii S. Bonaventurae, 1883, s. 11. Wszystkie dzieła, które nie doczekały się polskiego przekładu, cytowane są za dziesięciotomową edycją Opera omnia z Quaracchi [dalej: Q].

17 Por. J. Ratzinger, Prawda $w$ teologii, dz. cyt., s. 29.

18 Zob. M.M. Ciccarelli, S. Bonaventura, maestro di vita spirituale, a cura di E. Frascadore, Montecalvo Irpino 1975, s. XVI, 255. Autor interpretuje stan wyniesionego do mistycznej więzi człowieka z Bogiem następująco: „La suprema unione nell'amore è dunque «docta ignorantia», perché l'anima finalmente è nella realtà, a contatto con la verità assoluta, di cui nulla sa dire. L'anima in certo qual modo dorme e in certo qual modo veglia. L'intelletto dorme, non sapendo esprimere nulla, ma la parte affettiva veglia beandosi nell'intimità col Diletto". M.M. Ciccarelli, S. Bonaventura, maestro di vita spirituale, dz. cyt., s. 238. 
wolny od wszystkich doczesnych ograniczeń zostaje wyniesiony poprzez łaskę i boskie światło, jakby porwany w ekstazie, by kontemplować bez przeszkód chwałę Boga najwyższego. Istotą takiego doświadczenia jest trwanie z Bogiem przez miłość, cel i szczyt ludzkich uczuć (apex affectus). Ten duchowy transitus ku Bogu, o którym mowa, dokonuje się na drodze powszechnie znanej i utrwalonej w teologii duchowości - także dzięki św. Bonawenturze - triadzie stopni rozwoju:

oczyszczenie (katharsis) $\leftrightarrow$ oświecenie (photismos) $\leftrightarrow$ spełnienie, tj. zjednoczenie (teleiosis)

Warto jednak przy tym zaznaczyć, że dla Bonawentury owa triplex via nie oznacza jakiejś konsekutywności, czyli następowania jednego stopnia drogi po drugim, jak to czasami zwykło się mylnie interpretować, lecz polega na ich harmonijnym przeplataniu się w przestrzeni łaski i wolnej odpowiedzi ze strony człowieka. Dlatego można mówić o dynamicznej drodze świętości, która zna chwile oczyszczenia, oświecenia i zjednoczenia we wzajemnym dopełnieniu ${ }^{19}$, mimo że oczyszczenie zawsze oznacza uwolnienie się duszy od grzechów, oświecenie - głębsze poznanie Boga, zjednoczenie zaś czy udoskonalenie - jej więź z Bogiem przez miłość. W oczyszczeniu dusza napełnia się pokojem, w oświeceniu ma możliwość zbliżenia się do prawdy, która ją coraz bardziej pociąga, natomiast w zjednoczeniu może zatopić się w miłości. Postęp zaś na tych etapach charakteryzujących generalnie rozwój duchowy duszy dokonuje się przez rozmyślanie, modlitwę i kontemplację.

\section{Kontemplacja jako cognitio speculationis extensae}

Warto zatrzymać się przez chwilę nad zagadnieniem kontemplacji, aby przynajmniej w zarysie odnieść się do jego teologicznej wykładni i określić funkcje, jakie spełnia w systemie doświadczalnego poznawania Boga. W tej materii szczególnie pomocne będzie sięgnięcie do zestawienia opinii, którego dokonał M. Gogacz. Zaobserwował on u komentatorów myśli św. Bonawentury pewną zgodność opinii, a mianowicie, że pomimo częstego posługiwania się pojęciem kontemplacji, Doktor Seraficki $\mathrm{w}$ żadnym $\mathrm{z}$ tych miejsc nie określił jednoznacznie, co przez nie rozumie ${ }^{20}$. Stąd też niektórzy sami usiłowali ustalić, czym tak naprawdę jest kontemplacja.

Tak więc P. Rémi i Jean de Dieu de Champsecret zgodnie podają, że kontemplacja w ujęciu Bonawentury jest „doświadczalnym poznaniem Boga”. Zdaniem pierwszego autora kontemplacja polega najwyraźniej na „doświadczalnym poznaniu Boga, w którym za pośrednictwem daru mądrości dusza cieszy się intuicyjnym odczuciem swego zjednoczenia z Bogiem przez miłość"21. Natomiast według drugiego

19 Por. F.M. Tedoldi, La dottrina di cinque sensi spirituali in San Bonaventura, Roma 1999, S. 302.

20 M. Gogacz, Apofatyka jako sposób opisu..., art. cyt., s. 375.

${ }^{21}$ „La contemplation est la connaissance expérimentale de Dieu dans la quellepar l'intermédiaire dud on de sagesse, l'âme jouit du sentyment intuitif de son union amoureuse avec Dieu”. Przytoczonej przez M. Gogacza definicji, podanej-jak to zaznaczył w przyp. 
nadprzyrodzona kontemplacja to „doświadczalne poznanie Boga ujętego w duszy, poznanego w Jego dziełach, szczególnie w działaniu łaski, poznanie utrwalające miłosne wejrzenie tam, dokąd kierują się wszystkie afektywne siły duszy"22.

Nawet jeśli w przypadku definicji P. Rémi nie ma pewności, skąd M. Gogacz ją zacytował - wyjaśniono tę kwestię w przypisie - nie zmienia to faktu, że kontemplacja określana jest jako poznanie doświadczalne i że jest szczególną łaską wieńczącą naturalny rozwój duchowy człowieka. Jednak pytanie, czy Bonawentura kontemplację rozumiał jako autentyczne doświadczenie mistyczne, pozostaje otwarte.

W Komentarzu do Sentencji Bonawentura wyróżnił kontemplację intelektualną kwalifikowaną rozumem (per donum intellectus) oraz mądrościową, którą wyróżnia dar mądrości (per donum sapientiae) ${ }^{23}$. Pierwszą określa się jako cognitio speculationis extense, czyli poznanie dokonujące się na drodze poszerzonej spekulacji, którego owocem jest wewnętrzny pokój dzięki zdobyciu prawdy (ad cognitionem veritatis $)^{24}$. Poznania tego na wszystkich jego etapach nie można jednak utożsamiać $\mathrm{z}$ intelektualną intuicją, jest ono bardziej, jak utrzymuje Bonawentura, wolnym, przenikającym - należałoby jeszcze dodać: trwałym - spojrzeniem duszy (contuitus) podtrzymywanym przez podziw ${ }^{25}$. Można by ten rodzaj kontemplacji określić jako

17 (s. 376), za: É. Longpré, Bonaventure. Doctrine mystique ou La vie surnaturelle, w: Dictionnaire de spiritualité. Ascétique et mystique, doctrine et histoire, publié sous la direction de M. Viller, assisté de F. Cavallera, J. de Guibert avec le concours d'un grand nombre de collaboratereurs, vol. 1, Paris 1936, k. 1797, nie można tam odnaleźć. Nie ma jej też w tekście samego P. Rémi: P. Rémi, Chronique de spiritualité franciscaine, „Etudes Franciscaines” 48 (1936), s. 234-235, który był cytowany przez E. Longprégo, przynajmniej nie w takiej wersji, jaka została podana wyżej. P. Rémi w swoim artykule stwierdza za Bissenem, że kontemplacja jest łaską wyjątkową (la contemplation est una grâce extraordinaire) w odróżnieniu od wiary będącej wspólną łaską wszystkich uczniów Chrystusa. I że jest powrotem do Boga przez poznanie i miłość (la contemplation est un retour à Dieu; un ,, regressus”, un „,reascensus”, par la connaissance et par l'amour). Co więcej, powrót ten jest upodobnieniem się do Trójcy Świętej przez udoskonalenie w nas Bożego obrazu (Le retour à Dieu est une assimilation à la Sainte Trinité par le perfectionnement de l'image divine en nous). Por. J.M. Bissen, Les conditions de la contemplation selon saint Bonaventure, „La France Franciscaine” 17 (1934), série 2, s. 387-404.

22 „Connaissance expérimentale de Dieu perçu dans l'âme, connu dans son oeuvre, en particulier dans l'action de la grace, et fixé d'un amoureaux regard où se portent toutes les énergies d'affection d'une âme". J. de Dieu de Champsecret, Introduction, w: Saint Bonaventure, Itinéraire de l'âme en elle-même, tłum. J. de Dieu de Champsecret, kom. L. de Mercin, Blois 1956, s. 100.

${ }^{23}$ Q III, d. 35, a. 1, q. 3, ad 3, s. 778). Ta sama myśl znajduje się w innym jego dziele, a mianowicie w Breviloquium [dalej: Q V], 5, 5, s. 258b: „Necesse habemus quiescere in optimo et hoc quantum ad intellectum veri et quantum ad affectum boni; primum fit per donum intellectus; secundum per donum sapientiae, in quo est quies".

${ }^{24}$ Q III, d. 35, a. 1, q. 3, ad 3, s. 778.

25 Powołano się w tym miejscu na wiarygodną opinię É. Longprégo, Bonaventure. Doctrine mystique ou La vie surnaturelle, art. cyt., k. 1797: „Elle consiste non dans une vision intu- 
współpoznanie Boga, ponieważ realizuje się ono na drodze rozumu. Innymi słowy, dusza poznaje Boga jako prawdę na drodze prostego współpoznania (per simplicem contuitum $)^{26}$, czyli dzięki rozumowi poznaje Boga razem z Nim, przebywającym w niej przez łaskę uświęcającą ${ }^{27}$.

W przypadku drugiej formy kontemplacji, czyli mądrościowej, powtarza się u komentatorów pogląd, że jest to poznanie doświadczalne (cognitio experientiae), którego owocem jest również pokój tak jak w kontemplacji intelektualnej, z tą jednak różnicą, że jego osiągnięcie nie łączy się z prawdą, lecz z miłością Boga jako dobra najwyższego. Mówiąc o umiłowaniu, czyli afektywnym zwróceniu się do Boga, Bonawentura przywołał głos św. Bernarda z Clairvaux, dla którego owo miłosne kosztowanie Boga możliwe jest dzięki darowi mądrości ${ }^{28}$. Nie ulega wątpliwości, że to, co warunkuje doświadczalny charakter poznania w tym rodzaju kontemplacji, to właśnie umożliwienie owego „kosztowania” Boga (disponere ad gustandum Deum), które - jak podkreślił M. Gogacz - ,jest doskonalsze niż współpoznanie,

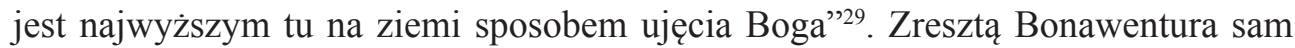
stwierdził, że najlepszy sposób poznania Boga polega na doświadczeniu słodkości ${ }^{30}$. Trzeba przy tym zauważyć, że doświadczenie słodyczy wywołane obecnością Boga nie jest postrzegane przez Doktora Serafickiego jako autentyczne oświadczenie mistyczne. Dzieje się tak, ponieważ Bóg, dobro najwyższe, nie jest ujmowany wprost, lecz w skutkach obecnej w duszy łaski (in effectu gratiae), która przenosi ją w sferę Boga $^{31}$. Aby zatem można było mówić o doświadczeniu mistycznym w sensie ścisłym, należy odnieść się do pojęcia ekstazy, która oznacza dosłownie porwanie duszy w Boga.

\section{Ekstaza i visio per raptum}

Ze wcześniejszych refleksji nad kontemplacją wynika, że poznanie Boga ma charakter wielostopniowy, przy czym bierze $\mathrm{w}$ nim udział zarówno dar rozumu, jak i dar mądrości, umożliwiające odpowiednio obcowanie raz z absolutną Prawdą, raz z nieskończoną Miłością. I właśnie owa wielostopniowość nie pozwala, aby kontemplację uznać za doświadczenie mistyczne w sensie ścisłym. Jest nim dopiero najwyższy i zarazem ostatni jej stopień określany przez Bonawenturę wi-

itive de Dieu, mais dans une contuition intellectuelle, c'est-à-dire dans une appréhension de Dieu dans un effet perçu sous l'influence du don d'intelligence".

${ }^{26}$ Q III, d. 35, a. 1, q. 3, ad 3, s. 778.

27 Zob. M. Gogacz, Apofatyka jako sposób opisu..., art. cyt., s. 377.

${ }^{28}$ Q III, d. 35, a. 1, q. 3, ad 3, s. 778: „Et hinc est, quod Bernardus appropriat donum intellectus fidei, quae assentit summae Veritati propter se; donum vero sapientiae appropriat caritati, cuius est disponere ad gustandum Deum".

29 M. Gogacz, Apofatyka jako sposób opisu..., art. cyt., s. 377.

${ }^{30}$ Q III, d. 35, a. 1, q. 1, ad 5, s. 775: „Optimus modus cognoscendi Deum est per experientiam dulcedinis".

31 Q II, d. 23, a. 2. q. 3, s. 545a: „Praesens mihi in effectu gratiae”. 
dzeniem przez porwanie (visio per raptum). Natomiast w Drodze duszy do Boga ów wyższy stopień kontemplacji miałby się dokonywać przez ekstazę umysłu (per mentis excessum) $)^{32}$.

Rodzi się zatem pytanie: Czy te dwa pojęcia odnoszą się do tej samej rzeczywistości, czy są tym samym? Czy poznanie przez porwanie jest tożsame z poznaniem dokonującym się przez przekroczenie umysłu, czyli ekstazę? ${ }^{33}$ Éphrem Longpré w cytowanym już wyżej tekście zauważa, że sam Bonawentura w Konferencjach o sześciu dniach stworzenia wyraźnie odróżnił raptus od extasis w słowach: „nie jest tym samym ekstaza i porwanie (nec est idem ecstasis et raptus)" ${ }^{\prime 34}$.

Istotne kryterium, dzięki któremu można stwierdzić, że pojęcia te nie są tym samym, to wyjątkowość pierwszego poznania - przeznaczonego w tym życiu dla nielicznych - i jednoczesna powszechność drugiego, będącego poniekąd celem życia wewnętrznego każdej duszy, którego należałoby tak pragnąć, jak pragnie się świętości. Świętość bowiem, która zakłada wcześniejsze oczyszczenie serca, jest bezpośrednim warunkiem ekstazy.

O ile ekstaza jest możliwym dla wszystkich wierzących intensywnym doświadczeniem pocieszenia, światłem oraz możliwością kosztowania słodyczy powiązania z Bogiem przez miłość - pod warunkiem, że człowiek oddzieli się od tego, co nie jest Bogiem, i od samego siebie ${ }^{35}$ - o tyle porwanie jest możliwe tylko dla niewie$\mathrm{lu}^{36}$, którym to zostaje udzielone jasne poznanie, inaczej widzenie Boga. Wówczas

32 Św. Bonawentura, Droga duszy do Boga ..., dz. cyt., 7,3, s. 69.

$33 \mathrm{~W}$ przeszłości zajmowano się tą problematyką bardzo szczegółowo, czego owocem są chociażby następujące cenne opracowania: J. Beumer, Zwei schwierige Begriffe in der mystischen Teologie Bonaventuras (,raptus” und ,extasis”), „Franziszkanische Studien” 56 (1974), s. 250-262; oraz M. Schlosser, Lux inaccessibilis. Zur negativen Theologie bei Bonaventura, „Franziskanische Studien” 68 (1986), Nr. 1-2, s. 3-140, przede wszystkim s. $98-130$.

34 Św. Bonawentura, Konferencje o sześciu dniach stworzenia albo oświecenia Kościoła, wydanie synoptyczne tekstu oryginalnego redakcji A oraz B, tłum. A. Horowski, Kraków 2008, III, 30, s. 125. Oto słowa komentarza do rozpatrywanej kwestii: „Au-delà de l'union extatique, il n'y a plus que le rapt. S. Bonaventure le distingue nettement de l'extase dans ses principaux écrits. Le rapt est une grâce extraordinaire, un privilège; il est caractérisé par la passivité pure. Dans toute connaissance in statu viae les espèces intelligibles extraites du sensible sont nécessaires; dans le rapt, l'âme atteint les raisons éternelles sans elles. En outre, elle n'expérimente plus seulement Dieu dans la grâce et l'amour, mais elle jouit de la vision intuitive de l'essence divine". É. Longpré, Bonaventure. Doctrine mystique ou La vie surnaturelle, art. cyt., k. 1838.

35 Św. Bonawentura, Konferencje o sześciu dniach stworzenia, dz. cyt., II, 32, s. 95. Tekst łaciński: „Separet se ab omni eo quod Deus non est et a se ipso”.

${ }^{36}$ Q III, d. 35, a. 1, q. 1, ad 4, s. 774b: „excessus in experimento divinae dulcedinis potius est laudabilis quam vituperabilis, secundum quod patet in viris sanctis et contemplativis, qui prae nimia dulcedine modo elevantur in ecstasim, modo sublevantur usque ad raptum, licet hoc contingat paucissimis". 
człowiek zostaje raptownie wyrwany ze swojego zwykłego stanu, wchodząc jakby w stan pomiędzy życiem a śmiercią, choć nie jest to jeszcze stan ostatecznej szczęśliwości, który osiąga się dopiero post mortem ${ }^{37}$. Tego typu doświadczenie Bonawentura przypisuje najwyraźniej św. Pawłowi: „Może ci, którzy zostali porwani, są wyjątkiem, co jak wierzymy, było u Pawła. Osoby te dzięki szczególnemu przywilejowi przekraczają stan pielgrzymowania. Nie mogą same tego doświadczenia wywołać, lecz jest im ono darowane" 38 .

Istotę poznania Boga przez porwanie doskonale oddaje komentarz É. Longprégo, który przytoczono w nocie 41. Mowa jest w nim o tym, że raptus to szczególna łaska (une grâce extraordinaire), wręcz przywilej (un privilège), i że polega na czystej bierności (la passivité pure) ze strony duszy. W tym samym komentarzu autor podkreśla, że ,dzięki poruszeniu przez Ducha Świętego i pod wpływem daru mądrości dusza doświadcza obecności Trójcy Świętej”39, przez co zostaje wyniesiona do najwyższego podobieństwa do trzech Osób Boskich.

Warto zaakcentować jeszcze jeden bardzo ważny wątek poznania przez porwanie. Otóż jak zauważa M. Gogacz, według Bonawentury człowiek obdarzony taką wyjątkową łaską poznania pozostaje wprawdzie in statu viae, ale szczyt jego duszy jest wchłonięty przez Boga. Liczy się w nim chwilowy akt chwały i afektywne jego przeżywanie, czyli odpowiednio widzenie Boga (visio) i kosztowanie Jego obecności (gustus). Aby jednak odróżnić widzenie w porwaniu od widzenia uszczęśliwiającego w wieczności możliwego dopiero po śmierci, Bonawentura precyzuje, że jedynie szczyt duszy zostaje porwany w ciemność (rapitur in caliginem), czyli do takiego poznania, któremu nie towarzyszy pełnia widzenia boskiej istoty ${ }^{40}$.

37 Zgodnie z rozpowszechnioną w scholastyce koncepcją teologiczną, którą głosił również Tomasz z Akwinu, porwanie (raptus) to ograniczona do krótkiej chwili łaska widzenia Boga w tym życiu bez wyniesienia istoty ludzkiej do stanu szczęśliwości. Św. Bonawentura, Konferencje o sześciu dniach stworzenia, dz. cyt., III, 30, s. 125: „Nie posiadają trwałego stanu chwały, lecz tylko akt chwały (Non habent habitum gloriae sed actum)”.

${ }^{38}$ Q II, d. 23, a. 2. q. 3, s. 544b: „Nisi fortassis in his qui rapiuntur, sicut credimus fuisse in Paulo, qui specialitate privilegii statum viatorum supergrediuntur, nec ibi aliquid agunt, sed solum aguntur".

39 É. Longpré, Bonaventure. Doctrine mystique ou La vie surnaturelle, art. cyt., k. 1838: „Sous la motion très forte du Saint-Esprit et l'influence du don de Sagesse, l'âme expérimente cette présence de la Trinité et acquiert le sens parfait de Dieu [...] en définitive elle s'assimile à Lui et devient un seul esprit avec Lui”. Mówiąc o upodobnieniu, É. Longpré odniósł się do tekstu Bonawentury z Konferencji o sześciu dniach stworzenia, XXII, 39, s. 609. Tekst łaciński według edycji z Quaracchi: „Quando facta est digna admissio et sancta perceptio, tunc rapitur in Deum sive in dilectum [...] quia iam sensit unionem et factus est unus spiritus cum Deo [...] et hoc est supremum in anima". Q V, s. 443.

${ }^{40}$ Q V, p. 5, c. 6, s. 260: „Quo quidem desiderio ferventissimo ad modum ignis spiritus noster non solum efficitur agilis ad ascendum, verum etiam quadam ignorantia docta supra se ipsum rapitur in caliginem et exessum". Zob. M. Gogacz, Apofatyka jako sposób opisu..., art. cyt., 386-387 (paragraf: Cechy mistycznego poznania per „,raptum”). 
Ważnym elementem w rozumieniu przez Bonawenturę kwestii poznania Boga przez porwanie jest wiązanie go z miłością jako działaniem woli. Doktor Seraficki uważał bowiem, że to doświadczenie nie może być rozpatrywane jedynie w kategorii pojęciowego ujęcia Boga, nawet jeśli bezdyskusyjnie towarzyszy mu intelektualny ogląd (visio), ale właśnie dzięki obecności Boga w duszy należy mówić przede wszystkim o miłosnym Jego kosztowaniu. Co więcej, twierdził, że doświadczenie to nie kończy się na kosztowaniu, ponieważ po nim przychodzi uścisk (amplexus) $)^{41}$, w którym główną rolę odgrywa duchowy zmysł dotyku. Dlatego ów mistyczny kontakt duszy i Boga nie dokonuje się na płaszczyźnie intelektualnej, lecz egzystencjalnej. Oznacza to, że człowiek przeżywa egzystencjalnie obecność niewyrażalnego, niepoznawalnego Boga, w następstwie czego może się cieszyć mistycznym odpocznieniem, identyfikowanym często ze śmiercią mistyczną. W niej to dochodzi do zawieszenia wszystkich aktywności człowieka z wyjątkiem oczywiście miłowania, które pozwala wejść w noc ducha, gdzie już niczego nie da się sformułować, niczego wypowiedzieć, niczego określić, niczego intelektualnie poznać ${ }^{42}$.

Skądinąd taki pogląd dowodzi spójności i konsekwencji całego systemu poznania Boga, bo jak wspomniano w założeniu ogólnym, to miłość jest dla Bonawentury ostatecznym kryterium tego poznania. Za Pseudo-Dionizym św. Bonawentura utrzymuje, że w nocy intelektu tylko miłość jeszcze widzi. To, co jest niedostępne dla rozumu, widzi jedynie miłość. I ponieważ miłość wykracza poza rozum, dlatego że widzi więcej, że wchodzi znacznie głębiej w tajemnicę Boga, to ona ma pierwszorzędne znaczenie w doświadczeniu mistycznym.

\section{Amplexus jako wartość jednocząca}

Powiedziano wyżej, że uścisk (amplexus) nabiera znaczenia poznawczego i że poznanie takie ma wartość jednoczącą, ponieważ poznana obecność jest objęta uściskiem miłości. W związku z tym afektywny zmysł dotyku (tactus) Bonawentura uznaje za najdoskonalszy i najbardziej duchowy w całym procesie poznawania Boga. Przyczyn tego stanu rzeczy, jak twierdzi Doktor z Bagnoregio, należy upatrywać w jednoczącej mocy uczucia afektywnego. To w nim poznający zostaje tak dalece dotknięty, czyli objęty, wypełniony miłością poznawanego, tj. Boga, że tworzą ze sobą jedną rzeczywistośćc ${ }^{43}$.

${ }_{41}$ Więcej na ten temat: F.M Tedoldi, Amplexus, w: Dizionario Bonaventuriano. Filosofia, teologia, spiritualità, a cura di E. Caroli, Padova 2008, s. 172-177.

42 Por. W. Słomka, Z dyskusji na temat: Apofatyka jako metoda analizy doświadczenia mistycznego, w: Św. Bonawentura. Życie i myśl, dz. cyt., s. 405.

${ }^{43}$ Q III, d. 13, dub. 1, s. 292a: „Circa affectionem vero triplicem contingit reperire statum: aut in remotione, et sic odoratus; aut in approximatione, et sic gustus; aut in unione, et sic tactus, qui est perfectior inter omnes sensus et spiritualior propter hoc, quo maxime unit ei qui est summus spiritus". 
Dystans, jaki dzieli poznającego i poznawanego, zostaje w ten sposób przezwyciężony poprzez moc miłosnego współistnienia, które jest zdolne doprowadzić do trwałej jedności. Dzięki zatem wolitywnemu uczuciu miłości osoba w momencie, w którym jednoczy się z Bogiem, poznaje Go i cieszy się Jego posiadaniem.

W związku z tym Bonawentura mówi często o niezbywalnej wartości afektywnego „wstępowania” (sursumactio) ${ }^{44}$, które znamionuje jednocząca potencjalność. Albowiem uczucie miłości wstępuje w pełniejszym potencjale poznania niż rozum, co z kolei gwarantuje większą możliwość zespolenia z obiektem poznawanym, większą niż ta, którą może zapewnić droga rozumu ${ }^{45}$.

W tym mistycznym wstępowaniu ku Bogu, w trakcie którego zmysły duchowe stopniowo osiągają pełnię swych percepcyjnej możliwości, pierwszorzędną rolę zaczynają odgrywać zmysły złączone ze sferą afektywną. Samo bowiem wstępowanie (modus ascendendi) staje się wówczas owocniejsze (fructuosior), czyli bardziej uszczęśliwiające, gdy dusza ze swoim uczuciem jest bliżej (proximior) obiektu uszczęśliwiającego. W traktacie Trzy drogi (De triplici via) Bonawentura zauważa: „Ten sposób wstępowania do Boga jest tym silniejszy, im siła wstępująca jest bardziej wewnętrzna, jest tym owocniejszy, im bliżej towarzyszy mu uczucie" ${ }^{46}$.

Można zatem uznać, że wzrok i słuch w pewnym momencie przekazują poznawcze działanie trzem innym zmysłom, spośród których najbardziej dotyk w jakiś szczytowym momencie poznania utożsamianym z pełnią jedności (apex affectus) zostaje przeniesiony i przemieniony przez Boga, tak jak w przypadku dotknięcia św. Franciszka na górze Alwerni ${ }^{47}$. A ponieważ dotyk ma największą zdolność jednoczącą (esse uniens), stąd też dusza nie może zadowolić się jakimś jedynie zewnętrznym przylgnięciem do obiektu poznawanego i umiłowanego (cognitum-amatum), lecz w swojej zdolności poznawczej schodzi w głębiny tajemnicy udzielającego się przez łaskę Boga, schodzi tam, gdzie rozum już nie sięga, gdzie sięga jedynie uczucie. To dzięki temu uczuciu można zejść aż na samo dno głębokości Chrystusa ${ }^{48}$.

44 Tym terminem Bonawentura wyraża zarówno działanie człowieka, a więc samą jego aktywność rozumianą jako zdolność „przekraczania siebie”, czyli „dążenia wzwyż”, jak i działanie Boga polegające na podniesieniu człowieka mocą łaski Ducha Świętego do szczęśliwej ekstazy.

${ }^{45}$ Q III, d. 35, a.u., q. 3, ad 5, s. 779b: „Et amplius ascendit affectio quam ratio, et unio quam cognitio”. Nieco wcześniej Bonawentura formułuje podobny wniosek: „multo altius ascendit affectus noster et vis affectiva quam cognitiva”. Q III, d. 31, a. 3, q. 1, s. 689.

46 Św. Bonawentura, Trzy drogi..., art. cyt., 3,13, s. 30.

47 Św. Bonawentura, Droga duszy do Boga..., dz. cyt., 7,4, s. 70: „Jeśli przejście ma być doskonałe, musi zaniknąć cała aktywność intelektualna, a szczyt wszelkich pragnień musi całkowicie przemienić się i ukierunkować na Boga. (In hoc autem transitu, si sit perfectus, oportet quod relinquantur omnes intellectuales operationes, et apex affectus totus transferatur et transformetur in Deum)".

48 Św. Bonawentura, Konferencje o szczęściu dniach stworzenia, dz. cyt., II, 32, s. 95: „Chrystus odchodzi wtedy, gdy umysł stara się za pośrednictwem oczu intelektualnych zobaczyć tę mądrość, ponieważ nie dociera tam intelekt, lecz uczucie [...], ponieważ uczucie 
Bonawentura chętnie odwołuje się do władzy afektywnej, ponieważ to ją właśnie uznaje za jedynie skuteczną siłę zdolną poszerzyć ludzkiego ducha, czyniąc go coraz bardziej capax Dei i uzdalniając do wejścia w jednoczące odpocznienie mistyczne. W Soliloquium zachęca więc: „rozszerz i rozciągnij uczucie i wejdź do radości Pana (dilata et expande affectionem et intra in gaudium Domini), jakiej w tym życiu ani oko nie potrafi doskonale widzieć, ani ucho słyszeć" ${ }^{49}$.

Aby jednak uczucie mogło się rozszerzyć i powiększyć swoją moc, aby zmysły mogły działać w całkowitej swej percepcyjnej potencjalności, należy je oczyścić najbardziej, jak to możliwe (affectus purgatissimus). Przed mającym nastąpić zjednoczeniem uczucie powinno się oczyścić, bo tylko wtedy może zostać oświecone (affectus illuminatus). Kto pragnie zbliżyć się do Boga, musi wpierw „umyć sobie nogi”, tj. oczyścić uczucie (lavare pedes, id est affectum). A wszystko po to, by zdjąwszy „obuwie” spraw doczesnych (discalceatus ab istis temporalibus), można było swobodnie biec w kierunku Boga ${ }^{50}$.

Jedynie z oczyszczonym uczuciem dusza będzie zdolna osiągnąć mistyczną jedność. Dopiero wtedy będzie mogła wejść w to niewytłumaczalne doświadczenie, którego nikt zrozumieć nie może, nikt - oprócz tego, kto doznaje go z woli Boga. Jedność mistyczną pojmie tylko ten, kto ją otrzyma, kto ją przyjmie, ponieważ wiąże się ona z doświadczeniem serca bardziej niż z pracą rozumu ${ }^{51}$. Jest to więc droga, która prowadzi do zbliżenia (ad copulam) i pocałunku (et osculum), a także uścisku (et amplexum). Mówiąc inaczej, wiedzie do nieodwracalnego zespolenia duszy $\mathrm{z}$ Bogiem tu na ziemi, niemalże do stopienia w jedno (adhaerentia conglutinans) poznającego i Poznawanego, kochającego i Kochanego.

Amplexus, a z nim tactus staje się najwyższym wyrazem poznania. Poznać w pełni jakąś rzeczywistość oznacza faktycznie „dotknąć jej”, doświadczyć jej, złączyć się z nią do tego stopnia, by tworzyć więź nierozerwalną. Szczyt poznania polega więc na miłosnym zespoleniu osobowym, kiedy ukochany, najpierw poznany oczami i wysłuchany w swoim orędziu, zostaje w jakiś sposób inkorporowany przez to zespolenie. W takim poznaniu dokonującym się w miłosnym przytuleniu dotknięcie staje się ,widzeniem rękami”, „wizją wypełnioną"52.

dociera aż do głębin Chrystusa (Tunc Christus recedit, quando mens oculis intellectualibus nititur illam sapientiam videre; quia ibi non intrat intellectus sed affectus [...], quia affectus vadit usque in profundum Christi)". Q V, s. 342a.

49 Św. Bonawentura, Rozmowa z samym soba. O czterech rodzajach modlitwy myślnej, tłum. C. Niezgoda, 4,1, w: Św. Bonawentura, Pisma ascetyczno-mistyczne, dz. cyt., s. 68.

50 Św. Bonawentura, De sancto Andrea Apostolo, sermo II [dalej: Q IX], s. 470b.

51 Św. Bonawentura, Droga duszy do Boga ..., dz. cyt., 4,3, s. 50: „Nikt nie zrozumie, jeśli go sam nie otrzyma, ponieważ wiąże się raczej z doświadczeniem serca niż pracą rozumu (Nemo capit, nisi qui accipit, quia magis est in experientia affectuali quam in consideratione rationali)".

52 Zob. F.M Tedoldi, Amplexus, art. cyt., s. 172-173. 


\section{Rodzaje mistycznego poznania}

Po omówieniu dróg mistycznego poznania warto przyjrzeć się jego rodzajom, czyli możliwym postaciom. O ile wcześniej mowa była głównie o zdolności i aparacie poznawczym człowieka, o tyle teraz tematem rozważań stają się rodzaje mistycznego poznania $\mathrm{i}$ ich rozpoznawane treści. $\mathrm{Z}$ bogatego materiału ascetyczno-mistycznego, jaki pozostawił po sobie Doktor Seraficki, można wyodrębnić mistykę światła i nocy, a także mistykę oblubieńcza i krzyża. Ten ostatni model jest skupiony na Oblubieńcu ukrzyżowanym.

Owe różne postaci mistyki pozostawione przez Bonawenturę w jego tekstach stanowią bezcenne źródło wiedzy życia wewnętrznego człowieka. Z jednej strony są wyrazem mistycznych doświadczeń św. Franciszka z łaską stygmatyzacji jako ich uwierzytelniającą pieczęcią, z drugiej odzwierciedlają bogactwo osobistych odniesień do Boga i Chrystusa, osadzonych na dobrze uporządkowanej wiedzy teologicznej.

\section{Mistyka ciemności i nocy}

„Mistyka ciemności” dobrze odzwierciedla tajemnicę Boga, Jego niewyrażalność, a co za tym idzie - ograniczoność poznawczą Jego duchowej rzeczywistości, o czym wspomniano wyżej, przywołując apofatyczność teologicznego poznania Pseudo-Dionizego tak bliską św. Bonawenturze. Owa niewyrażalność, niemożliwość widzenia Boga przyzywa zatem pojęcie mistyki ciemności, zgodnie z którą Bóg może być poznawany doświadczalnie ponad rozumem na sposób komunii wewnętrznej. Rozważa się ją jednak bardziej jako relację miłości niż wizji. To dlatego zmysł dotyku, jak chciał Bonawentura, a nie wzroku będzie odgrywał $\mathrm{w}$ niej dominującą rolę. Jeszcze inaczej widział całą sprawę Grzegorz z Nyssy, który w swojej refleksji nad mistyką ciemności dowartościował zmysł smaku, który miałby zastąpić powonienie. Uważał bowiem, że jak owoc następuje po kwiecie, tak smak następuje po zapachu ${ }^{53}$.

Grzegorz z Nyssy rozwija proces poznania mistycznego wokół tajemnicy Eucharystii, łącząc ekstazę mistyczną z ekstazą eucharystyczną, ponieważ - jak utrzymuje - zarówno jedna, jak i druga prowadzi do kosztowania słodyczy najwyższego Boga $^{54}$. W jednej ze swoich homilii pyta retorycznie: „Czy jest coś bardziej wzniosłego od bycia w Tym, którego się kocha, i mieć Tego, którego się kocha w swo-

$53 \mathrm{Na}$ ten temat zob. wnikliwe i niezwykle aktualne studium o dorobku Nysseńczyka: J. Danièlou, Platonisme et théologie mystique. Essai sur la doctrine spirituelle de saint Grégoire de Nysse, Paris 1944. Szczególnie poleca się trzecią jego część zatytułowaną: La ténèbre ou de l'amour, s. 173-307.

54 J. Danièlou, Platonisme et théologie mistique..., dz. cyt., s. 245: „Le rapprochement de l'extase mystique et de l'extase eucharistique est remarquable. Toutefois il faut noter qu'il y a une équivoque sur le mot extase. Il est pris d'abord au sens spécifiquement mystique, que Grégoire connaît, pour marquer la sortie de l'esprit hors de soi. Mais ensuite, il a le sens plus général, que l'on trouve chez Origène, de la transformation en Dieu par la grâce et en particulier par l'effet des sacrements". 
im wnętrzu?"55. Trzeba nadto podkreślić, że ekstaza, o której mowa, jest afektywną przemianą w Bogu, która się urzeczywistnia w mocy łaski sakramentalnej ${ }^{56}$.

Do tego przemieniającego charakteru laski (de la transformation en Dieu par la grâce), stanowiącego nerw sakramentalnej ekstazy u Grzegorza z Nyssy, Bonawentura dodaje wątek miłosnej afektywności. Właśnie dlatego, że w dojściu do Boga rozum napotyka na nieusuwalne przeszkody, jedyną możliwą ścieżką wejścia w ciemność boskiej tajemnicy jest uczucie miłości. Dusza, która kocha, widzi i rozpoznaje boskie sprawy bez porównania głębiej i szczerzej niż za pomocą samego wysiłku intelektualnego. Tylko bowiem miłość jest w stanie odnaleźć światło w najgęstszym mroku i tylko ona ufa ciemnościom, przed którymi rozum się zatrzymuje. Tylko miłość może biec bez znużenia w mroku nocy, gdy rozum słabnie i wycofuje się $\mathrm{z}$ lękiem, ponieważ nic nie widzi.

Dlatego w dziełku Chrystus jeden nauczyciel wszystkich, w którym Bonawentura z naciskiem powtarza, że miłość jest doskonałym wypełnieniem Prawa oraz kluczem obydwu Testamentów, wybrzmiewa mocno postulat, aby wszyscy zmierzali do zjednoczenia w miłości jako do celu ${ }^{57}$. W Chrystusie i Jego miłości widzi on wykładnię doświadczalnego poznania Boga. Chrystus bowiem jest „pastwiskiem” i „pasterzem” jednocześnie ${ }^{58}$. Jest pastwiskiem, czyli przestrzenią kosztowania boskiej słodyczy, pełni bóstwa, która się w Nim ukryła. Jest pasterzem, który wprowadza dusze do komunii ze sobą. Intuicja Bonawentury odkrywa fundamentalną prawdę, że słowa i czyny Chrystusa miały przekonać stworzenie o miłości Boga! Aby być z człowiekiem, Jezus pokonał drogę wcielenia i drogę krzyżową. W ten sposób dał możliwość doświadczyć człowiekowi w miłości tego, czego rozum nie ogarnia.

Wszystko, przez co Bóg przeprowadza człowieka w ciemności wiary, jest po to, by lepiej pojął on tajemnice, które mają się stać jego udziałem. Poznanie bowiem rodzi i pogłębia umiłowanie ${ }^{59}$.

\section{Mistyka oblubieńcza}

Intymną wspólnotę współistnienia, która najlepiej oddaje głębię relacji między Bogiem a człowiekiem, zwykło się określać mistyką oblubieńczą. Miłość bowiem jako

55 Grzegorz z Nyssy, In Canticum Canticorum homiliae, hom. VI (PG 44, k. 890d-892a): „Qui enim est altius, quam esse in ipso qui desideratur, aut eum qui desideratur in seipsum suscipere?”. Przekład homilii: Grzegorz z Nyssy, Homilie do Pieśni nad Pieśniami, wstęp, tłum., przypisy M. Przyszychowska, Źródła Myśli Teologicznej 43, Kraków 2007, homilia VI, s. 99-111.

56 J. Danièlou, Platonisme et théologie mistique..., dz. cyt., s. 245: „L'action sacramentelle marque ainsi la dépendance de la vie mystique à l'égard de l'action objective du Christ".

57 Św. Bonawentura, Chrystus jeden nauczyciel wszystkich, tłum. S. Kafel, III, 26, w: Św. Bonawentura, Pisma ascetyczno-mistyczne, dz. cyt., s. 339.

58 Św. Bonawentura, Chrystus jeden nauczyciel wszystkich, art. cyt., III, 26, s. 339.

59 Por. Św. Bonawentura, Trzy drogi..., art. cyt., 3,13, s. 30. 
ogniwo wiążące ustanawia pomiędzy nimi coś więcej niż zwykłą komunię życia, tworzy realną więź egzystencjalną. W tej koegzystencji stroną aktywną jest Bóg, gdyż to On jest pierwszym obdarowującym, On zapewnia i podtrzymuje mistyczną ekstazę duszy, czyli pozwala jej bytować w sobie poza sobą i ponad tym wszystkim, co nie jest Bogiem. W oblubieńczym uścisku mistycznym to nie dusza tak naprawdę przyjmuje miłość Bożą, ale odwrotnie, to miłość ją przyjmuje. Mocą Ducha Świętego, Ducha miłości, dusza pociągnięta lub wręcz porwana zostaje na takie wyżyny chwały, na jakie może wejść, będąc jeszcze w ciele. Wówczas to dokonują się mistyczne zaślubiny, kiedy zarówno dusza, jak i Bóg dają się posiąść nawzajem.

Bonawentura w licznych tekstach nawiązuje do symboliki starotestamentowej Pieśni nad Pieśniami, w której oblubieńczość jest znamieniem głębi intymnej więzi kochających się osób ${ }^{60}$. Na przedłużeniu tradycyjnej wykładni nauczania Kościoła o jedności oblubieńczej chętnie mówi o pewnym gradualnym wstępowaniu ku Bogu, w którym we wzajemnym wolnym obdarowaniu odnajdują się dwie miłości: boska i ludzka. Kiedy więc dusza w całej swej wolności zgadza się na to wyniesienie, Bóg zstępuje natychmiast, biorąc ją w posiadanie. W tym oblubieńczym związku, kiedy Bóg coraz bardziej odsłania duszy tajemnice nieba, pogłębia się uścisk serc, a wzajemne przylgnięcie zacieśnia się do tego stopnia, że Bóg staje się dla duszy jedynym i całkowitym pragnieniem (totus desiderabilis) ${ }^{61}$. Kto znajdzie się w takim uścisku, nie ustanie, jeśli nie posiądzie go miłość. Tylko zaślubiający ogień Ducha Bożego może ugasić pragnienie serca, które Bóg wybrał na oblubieńca bądź oblubienicę.

W dziele Trzy drogi, w końcowej jego części, można znaleźć jakby podsumowanie rozważań o jednoczącej drodze zaślubin, której stopnie wyrażają całą dynamikę wznoszenia się duszy do Boga. Bonawentura stwierdza m.in.: „Czujność niech cię budzi z powodu rychłego przyjścia Oblubieńca; zaufanie niech cię umacnia z powodu Jego niezawodności; pożądanie niech cię zapala z powodu Jego słodyczy; zachwycenie niech cię ukoi z powodu Jego piękna; radość niech cię upoi z powodu pełni Jego miłości; tak by pobożna dusza zawsze mówiła w sercu swoim do Pana: Ciebie szukam, w Tobie mam nadzieję, Ciebie pragnę, do Ciebie się wznoszę, Ciebie przyjmuję, w Tobie się raduję, i w końcu do Ciebie należę"

Założenie, że dusza ludzka jest prawdziwą umiłowaną przez Boga oblubienicą, której dążenia i pragnienia powinny wznosić się ponad to, co zmysłowe, Bonawentura rozważał w sposób oryginalny w dziele Soliloquium. Ta specyficzna rozmowa z samym sobą jest próbą naszkicowania przez człowieka - rzecz jasna, w konfrontacji ze słowem Bożym - własnej tożsamości duchowej z całym bagażem doświadczeń zewnętrznych i wewnętrznych. To obraz człowieczeństwa naznaczonego konkretnym celem, sięgającym poza sferę życia przyrodzonego.

\footnotetext{
60 Zob. Q V, s. 253a.

${ }_{61}$ Św. Bonawentura, Trzy drogi..., art. cyt., 3,13, s. 30.

62 Św. Bonawentura, Trzy drogi..., art. cyt., 3,8, s. 28.
} 
Już w pierwszym rozdziale dzieła, którego treścią wiodącą jest oblubieńcza relacja z Jezusem i jej duchowe następstwa, Bonawentura barwnie wyraża zachwyt duszy, która spotyka swego umiłowanego: „A nie wiedziałam, o dobry Jezu, jak bardzo Twój uścisk jest słodki, jak bardzo Twój dotyk - godziwy, jak bardzo Twoje towarzystwo rozkoszne. Bo chociaż pokochałam Cię, jestem czysta; bo chociaż dotknęłam Cię, jestem niewinna; bo chociaż przyjęłam Cię, jestem dziewicza. O najsłodszy Jezu! Twój uścisk nie plami, lecz oczyszcza; Twój dotyk nie brudzi, lecz uświęca. O Jezu, źródło wszelkiej słodyczy i przyjemności, jakże dużo masz rozkoszy, godziwości i radości, kiedy «lewicą» swej wiecznej mądrości i poznania podpierasz mą głowę, to znaczy mój rozum, a «prawicą» swej Boskiej łaskawości i miłości obejmujesz mnie, to znaczy mą wolę. Biada mi, nędznej! Któż mógłby doznać takiej słodyczy, przyjemności i rozkoszy, jak ta, kiedy spoczywa w ramionach Oblubieńca i kiedy szczęśnie zasypia wśród pocałunków takiego Króla i Przyjaciela? [...] Oby łaknęła tylko Ciebie, źródło życia, źródło wiecznego światła, strumieniu prawdziwej rozkoszy. O Ciebie niech się ubiega, Ciebie szuka, Ciebie znajduje i w Tobie słodko odpocznie"63.

Mistyka oblubieńcza, tak jak ją widzi Bonawentura, ujawnia jedną prawidłowość, a mianowicie, że gdy dusza pozwala się posiąść Bogu, On pozwala się posiąść jej. Oznacza to, że w oblubieńczym zjednoczeniu mistycznym dokonuje się swoista wymiana serc Oblubieńca i oblubienicy. Przyjąć kogoś do swojego serca, to znaczy dosłownie posiąść go i poślubić, utworzyć z nim więź za wzór więzi małżeńskiej (quasi matrimonialiter) - jak określa ją Doktor z Bagnoregio - kiedy Oblubieniec i oblubienica stają się jednym.

\section{Mistyka krzyża}

Mistyka oblubieńcza znajduje swój najpełniejszy wyraz w mistyce krzyża. Dla Bonawentury, dla którego stygmatyzacja św. Franciszka była punktem odniesienia w interpretacji naśladowania Chrystusa, męka i krzyż stanowią uprzywilejowane miejsca identyfikacji duszy-oblubienicy z Oblubieńcem. Chrystus Oblubieniec jest bowiem Ukrzyżowanym, którego należy kontemplować sercem, ku Niemu kierować wzrok, słuch i ku Niemu wyciągać ramiona. W szóstym rozdziale $O$ doskonałości życia Doktor Seraficki wyznaje, że ,jest rzeczą konieczną, aby ten, kto chce zachować niewygasłą pobożność w sobie, często, a właściwie zawsze oglądał oczyma serca Chrystusa umierającego na krzyżu. Dlatego Pan powiedział w Księdze Kapłańskiej: «Ogień na moim ołtarzu zawsze będzie płonął; będzie go podsycał kapłan, podkładając drzewo codziennie» (Kpł 6,5) ”64. Nieco wcześniej wyjaśnił, że „ołtarzem Bożym” jest ludzkie serce i że na nim powinien zawsze płonąć ogień żarliwej pobożności, który należy podsycać codziennie drzewem krzyża Chrystusowego i pamięcią Jego męki ${ }^{65}$.

63 Św. Bonawentura, Rozmowa z samym soba..., art. cyt., 1,17-18, s. 42.

${ }^{64}$ Św. Bonawentura, Do Sióstr o doskonałości życia, tłum. S. Kafel, 6,1, w: Św. Bonawentura, Pisma ascetyczno-mistyczne, dz. cyt., s. 132.

65 Św. Bonawentura, Do Sióstr o doskonałości życia, art. cyt., 6,1, s. 132. 
Zachęta do częstego spoglądania na Ukrzyżowanego i medytowania Jego męki $\mathrm{z}$ jednej strony ma ustrzec duszę przed zmarnowaniem wielkiej ceny, jaką Chrystus zapłacił na krzyżu, by wykupić człowieka z niewoli grzechu, z drugiej zaś pobudzić go do czynienia dobra oraz do szukania otuchy i pocieszenia w smutnych i uciążliwych momentach życia.

Bonawentura pisał o tym następująco: „Strzeż się, abyś nie była niewdzięczna wobec takiego dobrodziejstwa, by tak wielka cena zapłacona za ciebie nie była zmarnowana, ale przyłóż ukrzyżowanego Jezusa Chrystusa «jak pieczęć do serca swego» (Pnp 8,6), aby jak pieczęć w miękkim wosku, tak odbić w sercu swoim twego oblubieńca, Jezusa, i mów z prorokiem: «serce moje stało się jak topniejący wosk» (Ps 22,15). Przyłóż Go także «jak pieczęć do swego ramienia» (Pnp 8,6), abyś nigdy nie przestała dobrze czynić, abyś nigdy nie zniechęciła się w pracy dla imienia Pana Jezusa, ale gdy zrobiłaś wszystko, wtedy zaczynaj od początku, jakbyś nic nie zrobiła. Gdyby zaś czasem zdarzyło się coś smutnego, coś uciążliwego, coś nieprzyjemnego, coś gorzkiego albo coś niewłaściwego wobec dobra, natychmiast biegnij do ukrzyżowanego Jezusa wiszącego na krzyżu i tam wpatruj się w cierniową koronę, w żelazne gwoździe, we włócznię przebijającą bok, tam rozważaj rany nóg i rany rąk, rany głowy, ranę boku, rany całego ciała, uświadamiając sobie, że Ten, który tak za ciebie cierpiał, który za ciebie tyle zniósł, jakżeż On cię ukochał. Wierz mi, że po takim wpatrywaniu się natychmiast stwierdzisz, że wszystko smutne stało się radosnym, wszystko uciążliwe - lekkim, wszystko nieprzyjemne - przyjemnym, wszystko gorzkie - słodkim i miłym, tak że i ty zaczynasz wołać i mówisz z błogosławionym Hiobem: «czego nie chciała przedtem tknąć się moja dusza, teraz dla uścisku [męki Chrystusa] jest moim pokarmem» (Hi 6,7), jak gdybyś mówiła: dobra, które przedtem wydawały mi się niewłaściwe dla mojej duszy, teraz z powodu udręki męki Chrystusa, którą widzę, stały się słodkie i przyjemne dla mnie" ${ }^{\prime 66}$.

Tekst zawiera istotne rozróżnienie. Otóż przywołując słowa Pieśni nad Pieśniami, Bonawentura mówi o ukrzyżowanym Jezusie, którego należy przyłożyć jako pieczęć do „serca” i do „ramienia”. „Pieczęć serca” wskazuje na sferę egzystencji człowieka (esse), ze szczególnym aspektem osobowej tożsamości, jakim jest bycie uczniem Ukrzyżowanego, czyli trwanie w bytowej zależności od Niego. Natomiast „pieczęć ramienia” przywołuje sferę ludzkiego działania (agere). Tej jednak nie sposób zrozumieć bez pieczęci serca. Dlatego możliwość przemiany goryczy wszystkich wymiarów życia w słodycz bierze się - Bonawentura wskazuje tu na zmysł smaku - z zanurzania ich w krwi Chrystusa tak jakby w przyprawie ${ }^{67}$.

Jeszcze doskonalszym odniesieniem do ukrzyżowanego Oblubieńca jest ukrycie się w Jego przebitym boku. W tym przypadku nie jest istotne samo tylko dotknięcie rany boku Jezusa, jak to relacjonuje Janowa Ewangelia o Tomaszu Apostole (zob. J 20,27), lecz duchowe wejście do Serca Pana, przepaści miłowania i oazy

\footnotetext{
66 Św. Bonawentura, Do Sióstr o doskonałości życia, art. cyt., 6, 11, s. 136-137.

${ }^{67}$ Por. św. Bonawentura, Do Sióstr o doskonałości życia, art. cyt., 6, 11, s. 137.
} 
pokoju. Bonawentura nawołuje do tego wejścia słowami o wyjątkowej mistycznej głębi: „Przystąp więc [...] krokami twoich uczuć do Jezusa zranionego, do Jezusa cierniem ukoronowanego, do Jezusa przybitego na krzyżu i ze św. Tomaszem apostołem nie tylko patrz na przebicie gwoźdźmi jego rąk, nie tylko włóż palec twój na miejsce gwoździ, nie tylko włóż twoją rękę w Jego bok, lecz wejdź zupełnie przez ranę boku aż do samego serca Jezusa i tam przemieniona w Chrystusa najżarliwszą miłością Ukrzyżowanego (ardentissimo Crucifixi amore in Christum transformata), przybita gwoźdźmi Bożej miłości, przebita włócznią serdecznego umiłowania, przeszyta mieczem najgłębszego współczucia, nie szukaj niczego innego, nie pragnij niczego innego, nie chciej w nikim innym znaleźć pocieszenia, jak tylko w tym, abyś z Chrystusem mogła umrzeć na krzyżu. A wówczas z Pawłem apostołem zawołasz i powiesz: «Z Chrystusem jestem przybity do krzyża. Żyję już nie ja, lecz żyje we mnie Chrystus» (Ga 2,19.20)" "68.

Bez wątpienia jest to tekst, jeden z wielu u Bonawentury, który ma nieocenione znaczenie dla rozwoju kultu Najświętszego Serca Pana Jezusa. Przez swą głęboką wrażliwość pasyjną i pobożność, którą budował również na wzorcu św. Francisz$\mathrm{ka}$, stał się zatem także heroldem serca Bożego ${ }^{69}$. Mistyka męki i krzyża prowadzi bezpośrednio do przebitego serca Pana, w którym ukryty jest cały żar miłości Boga Ojca. Można powiedzieć, że to boskie serce, zranione i cierpiące, jest dla Bonawentury punktem centralnym mistyki krzyża, niejako jej nerwem. A dzieje się tak, ponieważ krzyż wyrasta z serca, z miłości, karmi się miłością. Bez niej nie byłby krzyżem Chrystusa, nie byłby znakiem zbawienia.

Mówiąc o najżarliwszej miłości Ukrzyżowanego, Bonawentura wskazuje przede wszystkim na jej przemieniającą moc, zdolną upodobnić oblubienicę do Oblubieńca. To zaś oznacza, że miłość Boga, właśnie dlatego, że jest nieskończona, nie wie, co znaczy „dość”. Ona zawsze pragnie więcej, dąży do pełni, porywa po to, by przemienić w siebie. Przywołany fragment Listu do Galatów o krzyżowej jedności Pawła z Chrystusem służy Bonawenturze za przykład boskiego upodobania wobec wybranych, których Chrystus wprowadza w głąb swego serca, odkrywając im tajemnice przed innymi zakryte.

68 Św. Bonawentura, Do Sióstr o doskonałości życia, art. cyt., 6, 2, s. 133. O otwartym boku, do którego Chrystus chce wpuścić duszę, Bonawentura wspomina także w Rozmowie z samym soba, art. cyt. 1,39, s. 50: „Rozważ, jaką była cierpliwość Oczekującego. Jak długo czekał na twoje przyjście! Jakżeż długo pobłażał ci w twoich grzechach! [...] O duszo, wróć wreszcie, bo Chrystus oczekujący cię na krzyżu skłania głowę, by cię ucałować, wyciąga ramiona, by cię uścisnąć, otwiera ręce, by cię wyposażyć, spoczywa na krzyżu, by cały zawisnąć, nogi daje przykuć, by na nim pozostać, a bok otworzyć, by cię do niego wpuścić".

69 Zob. R.H. Kośla, Bonawenturiański wktad w rozwój doktryny i kultu Najświętszego Serca Jezusa, w: Bonawenturiański system myślenia. Pytanie o aktualność (1217-2017). Materiaty Międzynarodowej Konferencji Jubileuszowej z okazji 800-lecia narodzin św. Bonawentury z Bagnoregio, Kraków, 1-2 czerwca 2017, Kraków 2018, s. 289-308. 
Obraz stygmatyzowanego Franciszka, tak bliski sercu Bonawentury, najpełniej streszcza teologiczne podstawy jego mistyki krzyża. W prologu Drogi duszy do $B o g a$, a więc dzieła, które powstało na górze Alwerni, wyjaśnia bezpośredni wpływ Franciszkowej stygmatyzacji na pojmowanie więzi krzyżowej, do jakiej Bóg może wezwać człowieka. Wyraził to w słowach: „Przebywając tam, rozważałem niektóre sposoby wznoszenia się naszego ducha ku Bogu. Między innymi przyszło mi na myśl owo cudowne zdarzenie, które tutaj właśnie przytrafiło się błogosławionemu Franciszkowi, mianowicie widzenie skrzydlatego serafina, który przypominał Ukrzyżowanego. Gdy to rozważałem, nagle uświadomiłem sobie, że widzenie przedstawiało kontemplacyjny zachwyt naszego ojca oraz wskazywało drogę, która do niego prowadzi. [...] Jedną z dróg, która do tego prowadzi, jest płomienna miłość Ukrzyżowanego [...]. Do Boga dochodzi się tylko przez Ukrzyżowanego, [...] nie dojdzie się do niebieskiego Jeruzalem, jeżeli nie przejdzie się, jak przez bramę, przez krew Baranka"70.

Żywa soteriologiczna treść o Ukrzyżowanym jako drodze i Jego krwi jako bramie wiodącej do obiecanej ojczyzny, jaka tu wybrzmiewa, stanowi teologiczną podstawę tej formy mistyki, jaką wyznacza pasyjność w ogólności, a krzyż w szczególności. Doświadczenie zaś mistyczne św. Franciszka wraz z łaską stygmatów jest dla Bonawentury jej doskonałym zobrazowaniem. Jak zauważa w prologu do Drzewa życia, Franciszek pragnął doskonale upodobnić się do ukrzyżowanego dla niego Zbawiciela, chciał też nieustannie nosić krzyż Jezusa zarówno duchowo, jak fizycznie ${ }^{71}$.

Dlatego Bonawentura poszedł jeszcze dalej w określeniu mistycznej więzi z ukrzyżowanym Zbawicielem. Otóż w jednym z kazań o pokucie mówił o konieczności upodobnienia się do Ukrzyżowanego, ale nie przez naśladowanie, lecz przez ukrzyżowanie. Chciał przez to dać do zrozumienia, że trzeba się dać ukrzyżować, ponieważ tylko wtedy będzie można w pełni korzystać z owoców drzewa życia. Wyraził to następująco: „Jeśli pragniesz, aby twoja dusza wydawała godne owoce, umartwiaj ciało! Bierz wzór z Chrystusa! Oto Jego słowa przekazane przez świętego Jana: «Jeżeli ziarno pszenicy, wpadłszy w ziemię, nie obumrze, zostanie samo jedno, ale jeśli obumrze, przynosi plon obfity». Chcąc wraz z Chrystusem korzystać z owoców drzewa życia, na którym On umarł, dajmy się z Nim razem ukrzyżować. Tylko wtedy będziemy wydatnie owocować na niwie duszy. Najmilsi! Kto chce znaleźć Pana, odnajduje Go w krzyżu. Stąd kto ucieka przed krzyżem, tym samym opuszcza też Pana. Gdzie krzyż, tam Pan; gdzie Pan, tam krzyż; tam też kieruj gorące pragnienia! Znalezienie ukrzyżowanego Pana nie mija bezowocnie, bo ubogaca je strumień lask Chrystusowych"72.

70 Św. Bonawentura, Droga duszy do Boga..., dz. cyt., prol. 2,3, s. 16-17.

71 Por. św. Bonawentura, Drzewo życia, thum. K. Żuchowski, prol. 1, w: Św. Bonawentura, Pisma ascetyczno-mistyczne, dz. cyt., s. 260-261.

72 Q IX, sermo I, s. 465: „Si vis igitur fructificare spiritualiter, necesse est, te mori carnaliter; in Ioanne exemplum de Christo: Nisi granum frumenti, cadens in terram, mortuum fuerit, 
Mówiąc o mistyce krzyża, nie można nie przywołać jej epifanicznego znaczenia, o którym Bonawentura rozprawia w Trzech drogach. Niektórzy jego komentatorzy wprost przyznają, że należy mówić o staurocentryzmie bonawenturiańskim, ponieważ krzyż staje się u niego jakimś hermeneutycznym kluczem w lekturze świata przyrodzonego i jego zjawisk, a także świata nadprzyrodzonego ${ }^{73}$. Przywołując objawienie Apokalipsy, Doktor Seraficki wskazuje na Baranka, który przez swoje cierpienie na krzyżu otworzył siedem pieczęci księgi (por. Ap 5,5). Jak mówi: „tą księgą jest znajomość wszystkich rzeczy, a było w niej zamknięte siedem tajemnic, które właśnie poprzez skuteczność męki Chrystusowej zostały wyjawione: przedziwny Bóg, rozumny duch, zmysłowy świat, upragniony raj, straszne piekło, czcigodna cnota, zawiniona kara"74. Według niego krzyż jest „kluczem, bramą, drogą i pięknem prawdy", czyli formą wszystkich form, formą najwyższą, dzięki której możliwa jest lektura wszelkiej rzeczywistości. Stąd też u Bonawentury krzyż będzie z jednej strony reprezentował najwyższy stopień objawienia Boga, z drugiej zaś najgłębsze aspiracje kontemplacji człowieka, gdyż jest kluczem, bramą i drogą ku przyobiecanej przez Boga wiecznej szczęśliwości.

\section{Zakończenie}

Jak można było zaobserwować, wśród wielu dróg wiodących ku poznaniu Boga Bonawentura, zainspirowany teologiczną intuicją Pseudo-Dionizego i praktyczną jej realizacją u stygmatyka św. Franciszka z Asyżu, za najdoskonalsze uważa poznanie mistyczne, czyli doświadczalne. Porównując cognitio i affectus daje do zrozumienia, że w mistycznym doznaniu człowiek nie odbiera Boga na sposób pojęciowy, lecz doświadcza Jego obecności. O ile poznanie rozumowe prowadzi do poznania Boga jako pierwszej przyczyny czy dobra najwyższego, o tyle poznanie afektywne warunkuje jedność z Bogiem jako Trójcą Osób w doskonałym współistnieniu. Kategorie, takie jak: raptus, amplexus, gustus czy tactus, które u człowieka są wyrazem uzdolnienia afektywnego, stanowią w systemie Bonawentury podstawę mistycznego doświadczenia obecności Boga. Apex mentis, czyli ta część ludzkiej duszy, która spotyka się ze Stwórcą, zastrzeżona jest dla afektu, tj. dla miłości, gdyż tylko ona ma zdolność jednoczącą.

Wiążącą rolę w wędrówce duszy do Boga odgrywa osoba Jezusa Chrystusa ukrzyżowanego. Dla Bonawentury to oś całej teologii i mistyki zarazem. Tylko On bowiem jest drogą do Ojca i wyłącznie przez Niego możliwe jest głębokie zjednoczenie z Trójjedynym Bogiem. Wcielone i ukrzyżowane Słowo Boże skupia wokół siebie wszystkie ludzkie dążenia, jest centrum, do którego zmierzają wysiłki

ipsum solum manet; si autem mortuum fuerit, multum fructum affert. Si igitur volumus habere fructum ligni vitae cum Christo, qui mortuus est et crucifixus, debemus cum ipso crucifigi, ut possimus spiritualem fructum facere".

73 Por. C.V. Pospíšil, Crux. Crucifixus, w: Dizionario Bonaventuriano, dz. cyt., s. 288-289.

74 Św. Bonawentura, Trzy drogi ..., art. cyt., 3, 3, 7º, s. 26-27. 
ascetyczne i pragnienia duszy. Ukrzyżowany Chrystus jest jedynym prawdziwym miejscem doświadczenia Boga przez człowieka. Dusza w takim poznaniu zostaje wyniesiona do ziemskiej antycypacji uszczęśliwiającej wiedzy o Bogu. Pozostając w kontemplacyjnej nocy wobec Jego tajemnicy, milczy i doświadcza swego rodzaju pokrewieństwa z Nim w miłości i przez miłość.

W owej Bonawenturowej myśli o wędrówce człowieka ku Bogu widać doskonale syntezę mistycznej wizji Pseudo-Dionizego i franciszkańskiej duchowości naznaczonej tajemnicą krzyża. Papież Benedykt XVI podczas jednej z audiencji, analizując pewne aspekty twórczości Doktora Serafickiego, wyraził się następująco: „Właśnie w mrocznej nocy Krzyża jawi się cała wielkość Bożej miłości; tam gdzie rozum już nic nie widzi, widzi miłość. Końcowe słowa jego «Wędrówki umysłu w Bogu» przy powierzchownej lekturze wydać się mogą przesadnym wyrazem pozbawionej treści pobożności; czytane natomiast w świetle teologii Krzyża św. Bonawentury są jasnym i realistycznym wyrazem duchowości franciszkańskiej"75.

Bonawentura ludzkiemu duchowi nakreślił drogę wspinaczki ku Bogu, osadzając ją na mocnym fundamencie ascezy (oczyszczenia - oświecenia - udoskonalenia). Jednocześnie podkreślił z naciskiem, że człowiek o własnych siłach, czyli bez wsparcia łaski, nie może się wznieść ku wyżynom Boga. Tylko sam Najwyższy może człowieka do siebie pociągnąć, inaczej: wynieść ku górze - jak to Bonawentura trafnie określa pojęciem sursum actio. Wyniesienie to dokonuje się z miłości i w miłości. Zakłada ono oczywiście drogę rozumu, ale jednocześnie przerasta go w gorejącej miłości ukrzyżowanego Chrystusa.

Bonawenturiańska teologia mistyczna jest więc owocem połączenia mistyki Pseudo-Dionizego i teologii krzyża, wyeksponowanej mocno w refleksji nad stygmatyzacją św. Franciszka, która inicjuje symbolicznie ascezę współodczuwania, czyli udziału w cierpieniach męki Chrystusa za grzechy świata. Tym samym Doktor Seraficki zapoczątkował w rodzinie franciszkańskiej, a także w samym Kościele wielki nurt mistyczny, który w niezwykły sposób podniósł i oczyścił ludzkiego ducha ${ }^{76}$.

\section{Bibliografia}

Benedykt XVI, Katecheza Benedykta XVI z 17 marca 2010 roku. Dla św. Bonawentury ostatecznym przeznaczeniem człowieka jest miłowanie Boga, spotkanie i zjednoczenie się Jego i naszej miłości, kosciol.wiara.pl/doc_pr/489637.Sw-Bonawentura-cz-III [dostęp: 1 XII 2021 r.].

75 Benedykt XVI, Katecheza Benedykta XVI z 17 marca 2010 roku. Dla św. Bonawentury ostatecznym przeznaczeniem człowieka jest miłowanie Boga, spotkanie i zjednoczenie sie Jego i naszej miłości, kosciol.wiara.pl/doc_pr/489637.Sw-Bonawentura-cz-III [dostęp: 1 XII 2021 r.].

76 Por. Benedykt XVI, Katecheza Benedykta XVI z 17 marca 2010 roku..., poz. cyt. Zob. także: N. Martínez-Gayol Fernández, M.J. Fernández, Á. Cordovilla, F. Millán, Odwzajemnienie miłości. Teologia, historia i duchowość wynagrodzenia, Kraków 2012, s. 203. 
Beumer J., Zwei schwierige Begriffe in der mystischen Teologie Bonaventuras (,raptus” und ,extasis”), „Franziszkanische Studien” 56 (1974), s. 250-262.

Bissen J.M., Les conditions de la contemplation selon saint Bonaventure, „La France Franciscaine" 17 (1934), série 2, s. 387-404.

Bonaventure Saint, Itinéraire de l'âme en elle-même, thum. Jean de Dieu de Champsecret, kom. L. de Mercin, Blois 1956.

Bonawentura św., Droga duszy do Boga i inne traktaty, thum. C. Napiórkowski, C. Niezgoda, S. Kafel, wstęp Paweł Milcarek, Biblioteka Christianitas 7, Poznań 2001.

Bonawentura św., Konferencje o sześciu dniach stworzenia albo oświecenia Kościo$\downarrow a$, wydanie synoptyczne tekstu oryginalnego redakcji A oraz B, thum. A. Horowski, Kraków 2008.

Bonawentura św., Pisma ascetyczno-mistyczne, Warszawa 1984.

Ciccarelli M.M., S. Bonaventura, maestro di vita spirituale, a cura di E. Frascadore, Montecalvo Irpino 1975.

Danièlou J., Platonisme et théologie mystique. Essai sur la doctrine spirituelle de saint Grégoire de Nysse, Paris 1944.

Dizionario Bonaventuriano. Filosofia, teologia, spiritualità, a cura di E. Caroli, Padova 2008.

Doctoris seraphici S. Bonaventurae, Commentaria in quatuor libros Sententiarum Magistri Petri Lombardi, vol. 1-4, Ad claras Aquas (Quaracchi) prope Florentiam: Ex typographia Colegii S. Bonaventurae, 1882.

Gilson É., La philosophie de saint Bonaventure, Paris 1943.

Gogacz M., Apofatyka jako sposób opisu doświadczenia mistycznego w tekstach św. Bonawentury, w: Św. Bonawentura. Życie i myśl, red. S.C. Napiórkowski, E.I. Zieliński, Niepokalanów-Warszawa 1976, s. 366-392.

Grzegorz z Nyssy, Homilie do Pieśni nad Pieśniami, wstęp, tłum., przypisy M. Przyszychowska, Źródła Myśli Teologicznej 43, Kraków 2007.

Heinzmann R., Filozofia średniowiecza, tłum. P. Domański, Kęty 1999.

Höllhuber I., S. Bonaventura maestro della vera mistica malintesa dal misticismo moderno, w: San Bonaventura maestro di vita francescana e di sapienza cristiana: Atti del Congresso internazionale per il 7 centenario di San Bonaventura da Bagnoregio, Roma 19-26 settembre 1974, a cura di A. Pompei, vol. 3, Roma 1976, s. 419-425.

Kośla R.H., Bonawenturiański wkład w rozwój doktryny i kultu Najświętszego Serca Jezusa, w: Bonawenturiański system myślenia. Pytanie o aktualność (1217-2017). Materiały Międzynarodowej Konferencji Jubileuszowej z okazji 800-lecia narodzin św. Bonawentury z Bagnoregio, Kraków, 1-2 czerwca 2017, Kraków 2018.

La Scala F., Il rapporto tra scienza e verità nel misticismo di s. Bonaventura, w: San Bonaventura maestro di vita francescana e di sapienza cristiana: Atti del 
Congresso internazionale per il 7 centenario di San Bonaventura da Bagnoregio, Roma 19-26 settembre 1974, a cura di A. Pompei, vol. 3, Roma 1976, s. 503-506.

Leon XII, Epistola summi pontifecis ad japoniae imperatorem (I),Acta Ordinis Fratrum Minorum" 9 (1890), s. 177-178.

Longpré É., Bonaventure. Doctrine mystique ou La vie surnaturelle, w: Dictionnaire de spiritualité. Ascétique et mystique, doctrine et histoire, publié sous la direction de M. Viller, assisté de F. Cavallera, J. de Guibert avec le concours d'un grand nombre de collaboratereurs, vol. 1, Paris 1936, k. 1760-1843.

Martínez-Gayol Fernández N., Fernández M.J., Cordovilla Á., Millán F., Odwzajemnienie miłości. Teologia, historia i duchowość wynagrodzenia, Kraków 2012.

Paweł VI, List z okazji siedemsetlecia śmierci św. Bonawentury (15 VII 1974), „L'Osservatore Romano" 114 (1974), nr 176, s. 1n.

Pseudo-Dionizy Areopagita, Pisma teologiczne. Imiona boskie. Teologia mistyczna. Listy, thum. M. Dzielska, Kraków 1997.

Ratzinger J., Prawda w teologii, thum. M. Mijalska, Kraków 2005.

Rémy P., Chronique de spiritualité franciscaine, „Etudes Franciscaines” 48 (1936), s. 228-236.

Rolandetti V., Esperienza metafisica ed esperienza mistica in S. Bonaventura: un sapere che ama e un amore che sa, w: San Bonaventura maestro di vita francescana e di sapienza cristiana: Atti del Congresso internazionale per il 7 centenario di San Bonaventura da Bagnoregio, Roma 19-26 settembre 1974, a cura di A. Pompei, vol. 3, Roma 1976, s. 387-394.

Schlosser M., Lux inaccessibilis. Zur negativen Theologie bei Bonaventura, „Franziskanische Studien" 68 (1986), Nr. 1-2, , s. 3-140.

Tedoldi F.M., La dottrina di cinque sensi spirituali in San Bonaventura, Roma 1999. Żynel A., Droga ku Bogu poprzez ascezę wedtug św. Bonawentury, w: Św. Bonawentura. Życie i myśl, red. S.C. Napiórkowski, E.I. Zieliński, Niepokalanów-Warszawa 1976, s. 348-365.

\section{Streszczenie}

Św. Bonawentura z Bagnoregio pozostawił po sobie wiele pism o typowo ascetyczno-mistycznym charakterze. Jego duchowa myśl - zwana często metafizyką mistyki chrześcijańskiej - koncentruje się wokół drogi, jaką pokonuje dusza ludzka, aby spotkać się z Bogiem w uszczęśliwiającym zjednoczeniu. Przedmiotem dociekań jest więc dynamika duchowego wysiłku człowieka, który w swojej otwartości jednoczy się z Bogiem Ojcem przez ukrzyżowanego Syna w Duchu Świętym. Mistyka w ujęciu Bonawentury nie ogranicza się do nadzwyczajnych stanów, lecz stanowi istotę całego życia chrześcijańskiego. To jemu zawdzięczamy organiczne i funkcjonalne wszczepienie ascezy w nurt życia mistycznego. 
Słowa kluczowe: teologia mistyczna, itinerarium, mistyka krzyża, wiedza uszczęśliwiająca, miłość jednocząca

\section{Elements of the Mystical Theology of St. Bonaventure of Bagnoregio}

\section{Summary}

St. Bonaventure of Bagnoregio left behind many writings of a typically ascetic and mystical character. His spiritual thought, often called the metaphysics of Christian mysticism, centers around the path that the human soul travels to meet God in beatific union. The subject of the inquiry is therefore the dynamics of the spiritual effort of man, who in his openness unites himself with God the Father through the Crucified Son in the Holy Spirit. According to Bonaventure, mysticism is not limited to extraordinary states, but is the essence of all Christian life. We owe him the organic and functional implantation of asceticism into the current of mystical life.

Keyword: mystical theology, itinerarium, mysticism of the cross, beatific knowledge, uniting love 